Piotr Koryś

https://orcid.org/0000-0003-4976-0505

Wydział Nauk Ekonomicznych Uniwersytetu Warszawskiego

\author{
Maciej Tymiński \\ https://orcid.org/0000-0002-7267-4595 \\ Wydział Nauk Ekonomicznych Uniwersytetu Warszawskiego
}

\title{
Zmarnowana dekada? Ekspansja inwestycyjna lat siedemdziesiątych XX wieku na tle polityki gospodarczej w okresie PRL*
}

\begin{abstract}
Abstrakt: W pierwszej połowie lat siedemdziesiątych XX w. pod rządami Edwarda Gierka w Polsce wprowadzono jeden z największych programów inwestycyjnych po II wojnie światowej. W jego realizacji kluczową rolę odgrywały technologie importowane z krajów wysokorozwiniętych oraz projekty inwestycyjne finansowane z zachodnich kredytów. Rezultaty modernizacji kraju, chociaż spowodowały krótkotrwałe przyspieszenie rozwoju, nie przyniosły oczekiwanych efektów.
\end{abstract}

Słowa kluczowe: Edward Gierek, program „harmonijnego rozwoju”, kryzys gospodarczy, inwestycje, gospodarka nakazowa, polityka gospodarcza, PRL.

Abstract: In the first half of the 1970s, under First Secretary Edward Gierek, one of the most extensive investment programmes after World War II was introduced in Poland. Technologies imported from highly developed countries and investment projects financed from Western loans played a crucial role in its implementation. Although they caused a short-term acceleration of development, this modernisation of the country did not bring the expected results.

Key w ords: Edward Gierek, 'harmonious development' programme, economic crisis, investment projects, command economy, economic policy, People's Republic of Poland.

\footnotetext{
* Niniejszy tekst został przygotowany przy wsparciu z grantu Narodowego Centrum Nauki nr 2015/19/B/HS4/03233.
} 
Boom gospodarczy w pierwszej połowie lat siedemdziesiątych XX w., wywołany polityką inwestycyjną ekipy Edwarda Gierka, był czasem bardzo szybkiego wzrostu gospodarczego. W ostatnich latach część ekonomistów oceniając dokonania tego okresu, podkreśla kluczowe znaczenie tej polityki dla modernizacji gospodarki Polski, w szczególności dla rozbudowy i unowocześnienia sektora przemysłowego. Autorzy ci wskazują także na znaczenie państwowych inwestycji dla rozbudowy infrastruktury energetycznej, telekomunikacyjnej i transportowej oraz szybkiego wzrostu liczby wybudowanych mieszkań ${ }^{1}$. W rezultacie, według tej interpretacji, polityka gospodarcza Gierka stała się podstawą trwałego unowocześnienia kraju, zbliżającego gospodarkę Polski do poziomu gospodarek wysokorozwiniętych.

Interpretacja ta pozostaje jednak w sprzeczności z większością analiz polityki gospodarczej lat siedemdziesiatych XX w. Jedną z pierwszych takich prac była książka Waldemara Kuczyńskiego ${ }^{2}$, w której autor już pod koniec lat siedemdziesiątych XX w. starał się zbadać m.in. przyczyny załamania polityki inwestycyjnej tego okresu. Wiele krytycznych opracowań ukazało się w latach osiemdziesiatych XX w., już po odwołaniu Gierka z pełnionego stanowiska ${ }^{3}$. Szczególnie dużo uwagi poświęcano problemowi zadłużenia gospodarki ${ }^{4}$. Krytyczna analiza polityki Gierka stała się też podstawą dyskusji na temat reformy gospodarczej w Polsce zarówno wśród ekonomistów związanych z rządem, jak i z demokratyczna opozycja ${ }^{5}$. W tym samym czasie pojawiły się analizy polityki gospodarczej Gierka na Zachodzie, z reguły pisane przez ekonomistów polskiego pochodzenia 6 . Po upadku komunizmu program inwestycyjny lat siedemdziesiątych XX w. nie był już tak istotnym tematem zainteresowania, niemniej opublikowano kilka analiz dotyczących tego okresu ${ }^{7}$, ukazały się też wspomnienia uczestników lub bezpośrednich obserwatorów tamtych wydarzeń ${ }^{8}$.

${ }^{1}$ Zob. np.: A. Karpiński, Drugie uprzemystowienie Polski - prawda czy mit?, w: Dekada Gierka. Wnioski dla obecnego okresu modernizacji Polski, red. K. Rybiński, Warszawa 2011, s. 13-26; P. Bożyk, Cywilizacyjne skutki „otwarcia” Polski na Zachód, w: Dekada Gierka..., s. 5-12; A. Karpiński, S. Paradysz, P. Soroka, W. Żółtkowski, Od uprzemysłowienia w PRL do deindustrializacji kraju. Losy zakładów przemysłowych po 1945 roku, Warszawa 2015.

${ }^{2}$ W. Kuczyński, Po wielkim skoku, Warszawa 1981.

${ }^{3}$ Zob. np.: U źródet polskiego kryzysu, red. A. Müller, Warszawa 1985.

${ }^{4}$ Zob. S. Jędrychowski, Zadtużenie Polski w krajach kapitalistycznych, Warszawa 1982.

${ }^{5}$ Reforma gospodarcza: propozycje, tendencje, kierunki dyskusji, red. R. Krawczyk, Warszawa 1981; zob. też: D. Grala, Reformy gospodarcze w PRL (1982-1989), Warszawa 2005; P. Koryś, M. Tymiński, Od socjalizmu do socjalizmu. Koncepcje reform gospodarczych $w$ PRL po wybuchach społecznych w 1956 i 1980 r., „Dzieje Najnowsze” 2016, nr 4, s. 125-140.

${ }_{6}$ Zob. np.: Z. Fallenbuchl, Polityka gospodarcza PRL, Londyn 1980; J.G. Zieliński, New Polish Reform Proposals, „Soviet Studies” 1980, t. XXXII, nr 1, s. 5-27.

7 Zob. np.: A. Ząbkiewicz, Koncepcja zagranicznej polityki kredytowej $w$ Polsce $w$ latach 1970-1980, Wrocław 1992; Ł. Dwilewicz, Reformy Bolestawa Jaszczuka i polityka gospodarcza epoki gierkowskiej, w: Dekada Gierka..., s. 73-120.

${ }^{8}$ Zob. np.: J. Rolicki, Edward Gierek. Przerwana dekada, Warszawa 1990; P. Jaroszewicz, Przerywam milczenie... 1939-1989, Warszawa 1991; Z. Rurarz, Bytem doradca Gierka, 
Program wprowadzany przez ekipę Gierka nie stanowił jedynej próby skokowej modernizacji gospodarki w PRL. Pierwszym takim projektem była intensywna industrializacja wprowadzana w ciagu pierwszych 10 lat po II wojnie światowej, a szczególnie w okresie realizacji planu 6-letniego (1950-1955). Błędy polityki stalinowskiej dyskutowano od połowy lat pięćdziesiątych XX w., a już na początku lat sześćdziesiątych Stefan Kurowski argumentował, że przyjęty wtedy model rozwoju nie daje możliwości nadrobienia dystansu, a tym bardziej dogonienia Zachodu ${ }^{9}$. Jego analiza, choć o bardziej ogólnym charakterze, odnosiła się także do Polski i tak była interpretowana. Niewiele później opublikowana została książka Jerzego Jedlickiego, stanowiąca kolejna zawoalowaną krytykę tego modelu rozwoju ${ }^{10}$. Wiele uwagi porażce modelu stalinowskiego poświęcili ekonomiści, którzy prowadzili dyskusję nad jej powodami już od czasu II Zjazdu Ekonomistów w 1956 r., a później w trakcie prac Rady Ekonomicznej ${ }^{11}$.

Celem niniejszej pracy jest analiza programu gospodarczego wprowadzonego przez Gierka, głównie znaczenia wzrostu wydatków inwestycyjnych w porównaniu z polityka gospodarczą prowadzoną przed 1970 r. w PRL, przede wszystkim w nawiazaniu do programu intensywnej industrializacji w pierwszej połowie lat pięćdziesiątych XX w. Polityka gospodarcza okresu stalinowskiego, z jej dążeniem do szybkiego uprzemysłowienia kraju, stanowi naturalny punkt odniesienia dla epoki boomu gospodarczego w okresie rządów Gierka kolejnej próby dokonania wielkiego skoku modernizacyjnego. Opierając się na statystykach pokazujących wskaźniki rozwoju gospodarczego Polski (zarówno oficjalnych statystykach Głównego Urzędu Statystycznego [GUS], jak i opracowaniach zagranicznych), postaramy się odpowiedzieć na pytanie o efektywność rozwiązań gospodarczych wprowadzonych przez Gierka, w szczególności $\mathrm{w}$ porównaniu z dokonaniami władz PRL w okresie intensywnej industrializacji, ale również w odniesieniu do polityki uprawianej przez Władysława Gomułkę.

Praca została podzielona na sześć części. W części I krótko charakteryzujemy kolejne fazy rozwoju gospodarczego PRL od II wojny światowej do upadku władzy komunistycznej w Polsce. W części II przedstawiamy założenia polityki gospodarczej ekipy Gierka. W częściach III i IV omawiamy skalę, strukturę i sposób finansowania inwestycji. W części V analizujemy rezultaty polityki gospodarczej Gierka w Polsce. Wreszcie w części VI prezentujemy analizę porównawczą polityk gospodarczych prowadzonych w PRL.

Warszawa 1990; W. Bień, Jak doszło do zadtużenia Polski za granica w latach 1970-1985. Wspomnienia uczestnika wydarzeń, Warszawa 2017.

${ }^{9}$ S. Kurowski, Historyczny proces wzrostu gospodarczego. Analiza trendów sekularnych na podstawie produkcji żelaza $i$ stali, Warszawa 1963.

10 J. Jedlicki, Nieudana próba kapitalistycznej industrializacji. Analiza państwowego gospodarstwa przemystowego w Królestwie Polskim XIX w., Warszawa 1964.

${ }^{11}$ Na temat tych debat zob. A. Witczak-Haugstad, A Discipline Divided. Polish Economists and the Communist Regime, 1945-1960, Trondheim 2008. 


\section{Cykl rozwojowy gospodarki PRL}

Polityka harmonijnego rozwoju zaproponowana przez ekipę Gierka była ostatnią próbą socjalistycznej modernizacji, a jednocześnie drugim z cykli polityczno-gospodarczych o takiej dynamice inwestycji. Porównywalną dynamikę obserwować można tylko w pierwszych latach po wojnie, w okresie obejmującym dwa plany gospodarcze (1946-1949 i 1950-1955). O ile w okresie ekspansji fiskalnej czasów stalinowskich i gierkowskiego boomu gospodarczego widać coroczny wzrost funduszu inwestycji, znacznie przekraczajacy $20 \% \mathrm{w}$ szczytowych latach cyklu, to w okresie gomułkowskim i w dekadzie lat osiemdziesiątych XX w. ta dynamika nie przekraczała istotnie $10 \%$ (por. rys. 1$)^{12}$.

Lata 1946-1956 to czas odbudowy po wojnie i forsownej industrializacji w oparciu o akumulację wewnętrzna, dokonująca się kosztem wyhamowania, a nawet spadku realnych wynagrodzeń za pracę. Poziom inwestycji był relatywnie niski na początku okresu, co potem umożliwiało osiaganie wysokiej dynamiki ich wzrostu. Szybka industrializacja opierała się na imporcie sowieckich technologii i rozwoju branż przemysłu typowych dla II rewolucji przemysłowej. W szczególności rozwijano przemysł ciężki i chemiczny, hutnictwo i przemysł zbrojeniowy. Stalinowska industrializacja i modernizacja polegała w związku z tym na wykorzystaniu dość starych technologii - dostęp do nich umożliwiał ZSRS. Wysoka dynamika wzrostu nakładów inwestycyjnych wiązała się zarówno z liczbą i skalą nowo uruchamianych przedsięwzięć, jak i ich kapitałochłonnością. Jednocześnie wzrost gospodarczy, a zwłaszcza wzrost produkcji przemysłowej w bardzo ograniczonym stopniu przyczyniał się do realizacji aspiracji ekonomicznych Polaków, ponieważ nie rozwijano branż majacych zwiąek z produkcją wyrobów konsumpcyjnych. Jedynym wyjątkiem były nakłady na budownictwo mieszkaniowe w miastach ${ }^{13}$.

Po śmierci Stalina nastapiło wyhamowanie wzrostów nakładów na inwestycje. Kryzys systemu władzy poskutkował masowymi protestami, korekta polityki społecznej i gospodarczej oraz ograniczoną odwilża polityczna. W wypadku polityki gospodarczej oznaczało to przede wszystkim zmianę relacji pomiędzy nakładami na inwestycje (akumulacja) a konsumpcja. Skala protestów społecznych w $1956 \mathrm{r}$. i obawa przed ich powrotem była zapewne istotnym czynnikiem wpływającym na reorientację polityki gospodarczej. Nowa koncepcja relacji polsko-sowieckich, ukształtowana w otoczeniu Gomułki,

12 Wszystkie źródła danych zostały opisane pod rys. 1.

${ }^{13}$ Szerzej zob. M. Bałtowski, Gospodarka socjalistyczna w Polsce. Geneza - rozwój-upadek, Warszawa 2009; A. Jezierski, B. Petz, Historia gospodarcza Polski Ludowej 1944-1985, Warszawa 1988; J. Kaliński, Etatyzacja gospodarki w okresie rzadów komunistycznych $w$ Polsce, „Kwartalnik Kolegium Ekonomiczno-Społecznego «Studia i Prace»” 2015, nr 4, s. 177-201; idem, Plan odbudowy gospodarczej. 1947-1949, Warszawa 1977; idem, Przemiany strukturalne $w$ gospodarce polskiej $w$ latach 1944-1970, Warszawa 1993; idem, Polityka gospodarcza Polski w latach 1948-1956, Warszawa 1987. 


\section{Rysunek 1. Dynamika wydatków inwestycyjnych $\mathrm{r} / \mathrm{r}$ (rok poprzedni $=1$ )}

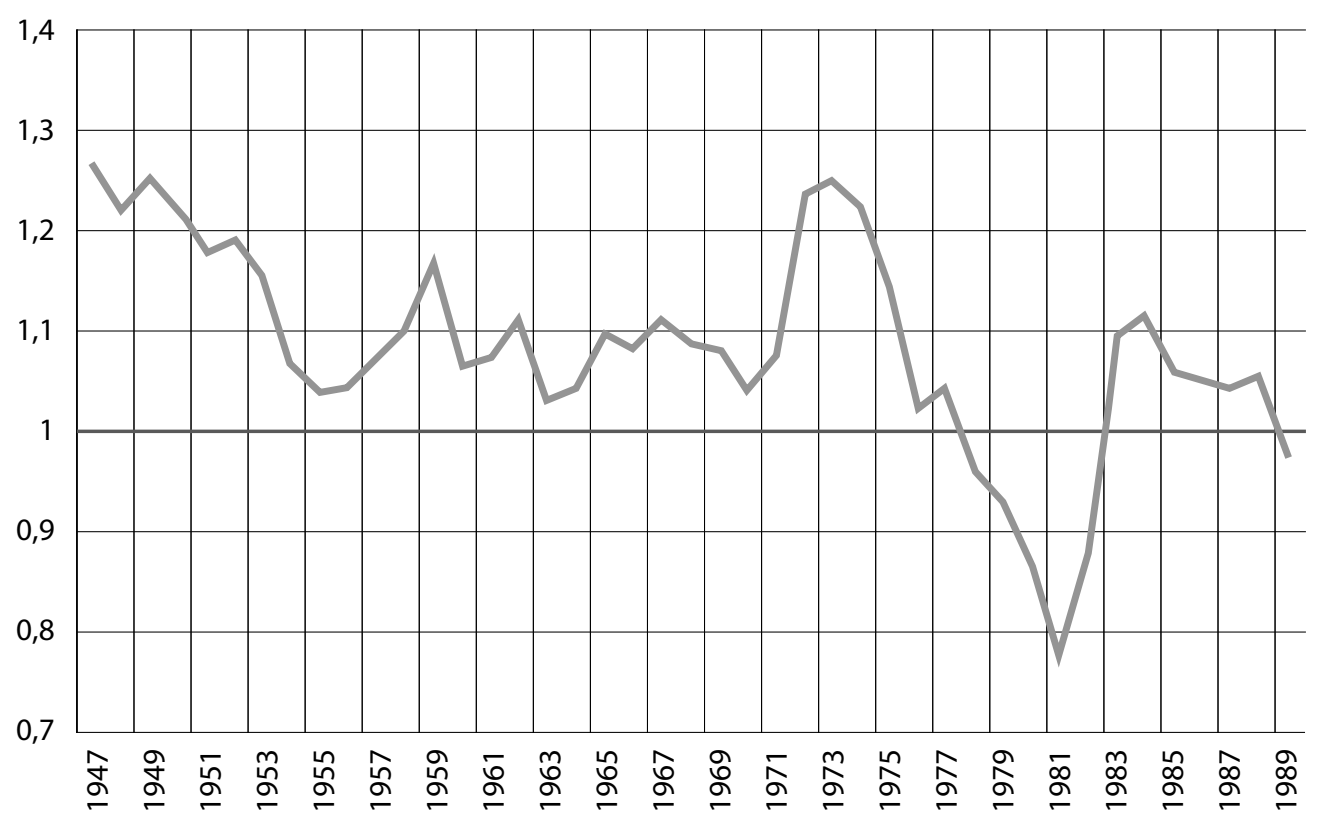

Źródła: Rocznik Statystyczny 1970, Warszawa 1970, s. 101; Rocznik Statystyczny 1975, Warszawa 1975, s. 131; Rocznik Statystyczny 1977, Warszawa 1977, s. 102; Rocznik Statystyczny 1979, Warszawa 1979, s. 115; Rocznik Statystyczny 1980, Warszawa 1980, s. 120; Rocznik Statystyczny 1985, Warszawa 1985, s. 179; Rocznik Statystyczny 1989, Warszawa 1989, s. 195.

Ceny zostały przeliczone do poziomu z $1984 \mathrm{r}$. w oparciu o indeksy łańcuchowe. W celu wygładzenia szeregu skorygowano dane dla lat 1949 i 1950. Według oryginalnych danych wzrost inwestycji w tych latach wyniósł aż 40\%, co wiązało się zapewne ze sposobem rozliczania Planu 1946-1949 i Planu 1950-1955. Nie ma żadnych przekonujących argumentów na rzecz jednorazowego gwałtownego wzrostu inwestycji w 1950 r., przed i po którym dynamika była zdecydowanie niższa.

a w szczególności przekonanie o konieczności zapewnienia elementarnej autonomii gospodarczej, wpłynęła z kolei na ograniczenie importu technologii z ZSRS. Bezpośrednim skutkiem odejścia od polityki zmniejszenia poziomu akumulacji, przy jednoczesnej bardzo ograniczonej możliwości zewnętrznego kredytowania rozwoju, był spadek dynamiki wzrostu nakładów inwestycyjnych. W czasach gomułkowskich rosły one w dość stabilnym tempie. Ekipa Gomułki realizowała program rozwoju w oparciu o zasoby wewnętrzne, z nieśmiałymi próbami importu technologii. Immanentną jego częścią stała się polityka deglomeracji inwestycji. Ostatnim etapem tej strategii rozwojowej był program selektywnego rozwoju, którego główny cel miało stanowić uniknięcie cyklicznego spowolnienia inwestycji i rozwoju ${ }^{14}$.

${ }_{14}$ Zob. Ł. Dwilewicz, Polityka selektywnego rozwoju w latach 1968-1970, w: Nauki ekonomiczno-społeczne i rozwój, red. K. Żukrowska, Warszawa 2008, s. 331-352; J. Kaliński, 
W okresie sprawowania władzy przez Gierka powrócono do koncepcji przyspieszonej industrializacji. Po doświadczeniach Gomułki z 1970 r. bezspornie nie można było realizować polityki inwestycyjnej opartej na zwiększonej akumulacji, skutkującej ograniczeniem konsumpcji. Dlatego wybrano inne niż wcześniej źródła finansowania, jak i strategię rozwojowa. Podstawowym źródłem finansowania były zewnętrzne pożyczki, a strategia rozwojowa obejmowała rozwój zarówno przemysłu ciężkiego, jak i sektorów zaspokajających potrzeby konsumpcyjne. Finansowanie rozwoju w oparciu o pożyczki w walutach wymienialnych stworzyło warunki do importu technologii z Zachodu na masowa, w porównaniu z wcześniejszymi okresami, skalę ${ }^{15}$.

Następstwem polityki inwestycyjnej Gierka, już w połowie lat siedemdziesiątych XX w., stało się załamanie dynamiki inwestycji w skali nieobserwowanej wcześniej, aż do spadków r/r. Wyhamowanie rozwoju, które doprowadziło do pierwszej w okresie realnego socjalizmu recesji na przełomie 1970 i 1980 r., znów przyniosło falę protestów społecznych i wymianę ekipy rządzącej. Skala protestów, która zaskoczyła władze, umożliwiła powstanie niezależnego ruchu społecznego, zorganizowanego jako związek zawodowy Solidarność. Na początku lat osiemdziesiątych rozpoczął się ostatni, dużo słabszy niż poprzedni, cykl inwestycyjno-rozwojowy. Tym razem powrócono do rozwoju w oparciu o zasoby wewnętrzne, uzupełnione o ograniczoną pomoc rzeczową i finansową ze strony $\mathrm{ZSRS}^{16}$.

\section{Program „harmonijnego rozwoju”}

Program ekspansji inwestycji w pierwszej połowie lat siedemdziesiatych XX w. miał od początku postawiony cel szybkiej modernizacji kraju. Już pod koniec 1970 r. I sekretarz PZPR Gierek stwierdzał, że nowa polityka gospodarcza musi „stawić czoła ekonomicznemu wyzwaniu, jaki stwarza szybki rozwój innych krajów, zapewnić Polsce należną i godna pozycję”, a „generalnym kierunkiem długofalowej strategii musi być modernizacja naszej gospodarki”. Wskazywał przy tym na „techniczną rekonstrukcję szeregu gałęzi przemysłu", wymieniając niemal wszystkie branże gospodarki ${ }^{17}$. Jednocześnie nowe władze zapewniały o podniesieniu stopy życiowej ludności poprzez zwiększenie konsumpcji.

Propozycje nowego otwarcia, na początku lat siedemdziesiątych XX w. jeszcze nieskonkretyzowane, były w znacznym stopniu odpowiedzią na bunt

Gomutkowskie dylematy modernizacji gospodarki, „Annales Universitatis Paedagogicae Cracoviensis. Studia Politologica” 2011, t. V, s. 41-50.

15 W. Kuczyński, op. cit., s. 99-114.

${ }^{16}$ D. Grala, op. cit.

17 E. Gierek, VIII Plenum KC PZPR, „Nowe Drogi” 1971 (numer specjalny). 
społeczny w 1970 r., wywołany polityką poprzednich władz. Pod koniec lat sześćdziesiątych Gomułka rozpoczął realizację programu selektywnego rozwoju, który miał się opierać na inwestycjach w branże rokujące największe nadzieje na przyśpieszenie wzrostu gospodarczego oraz produkcję eksportową. Program ten uderzał w interesy tych branż przemysłowych, których nie zamierzano preferować w nowym programie. Jednocześnie Gomułka, aby ograniczyć konsumpcję, zdecydował się na podwyżki cen, co bezpośrednio przyczyniło się do wybuchu strajku i zamieszek. W efekcie nowe władze dość szybko zdecydowały się na podwyżki płac i ograniczenie wzrostu cen ${ }^{18}$.

W zaistniałej sytuacji propozycja nowego programu nie mogła ograniczać aspiracji społecznych (poziomu konsumpcji), a raczej powinna odpowiadać na rozbudzone oczekiwania. Jednocześnie sytuacja gospodarki - jak zauważył Kuczyński - wymagała podjęcia działań modernizacyjnych, ponieważ przez całe lata sześćdziesiąte rosnącemu zatrudnieniu i zaangażowaniu kapitału odpowiadały coraz niższe przyrosty produkcji. Dowodziło to niezbędności rekonstrukcji technicznej gospodarki, poprawiającej jej produktywnośćc ${ }^{19}$. Wreszcie konieczność zachowania dobrych relacji z własnym aparatem gospodarczym i politycznym wymuszała rezygnację z modelu „selektywnego" rozwoju na rzecz rozwoju - jak to później określono - „harmonijnego”, co oznaczało szansę dostępu do środków inwestycyjnych dla wszystkich branż (a w praktyce preferowało najsilniejsze grupy interesu).

W warunkach ograniczonej dostępności kapitału pogodzenie tych wszystkich celów (konsumpcyjnego i modernizacyjnego, zaspokojenie popytu inwestycyjnego różnych lobby regionalnych i gospodarczych) przy użyciu dotychczasowych środków było niezwykle trudne czy wręcz niemożliwe. Jedyne rozwiązanie stanowiło znalezienie zewnętrznego źródła kapitału niezbędnego zarówno do prowadzenia inwestycji, jak i podniesienia poziomu konsumpcji. Sprzyjała temu sytuacja międzynarodowa, jak wskazywał Zbigniew Fallenbuchl - z powodu gorszej koniunktury na Zachodzie „eksporterzy dóbr inwestycyjnych [...] poszukiwali nowych rynków i byli gotowi dostarczać swoje towary na kredyt", z kolei banki - oferować kredyty ze względu na niższe zapotrzebowanie na kapitał $\mathrm{w}$ swoich krajach ${ }^{20}$.

Omówione uwarunkowania złożyły się na koncepcję „drugiej industrializacji” (pierwsza miała miejsce w latach 1950-1955) opierającej się na inwestycjach w przemysł i infrastrukturę, finansowanych z kredytów pozyskiwanych zagranica. Wprowadzany program miał doprowadzić do skokowego unowocześnienia polskiego przemysłu poprzez wykorzystanie urządzeń i licencji zakupionych na Zachodzie. W przeciwieństwie do omawianego wyżej programu „selektywnego" rozwoju nie został on jednoznacznie ukierunkowany branżowo,

\footnotetext{
${ }^{18}$ Ł. Dwilewicz, Reformy Bolestawa Jaszczuka..., s. 97-98.

${ }^{19}$ W. Kuczyński, op. cit., s. 78.

20 Z. Fallenbuchl, Polityka gospodarcza..., s. 27.
} 
co zgadzało się z oczekiwaniami aparatów gospodarczego i partyjnego, które były biorcami funduszy inwestycyjnych, realizujac nowe projekty przemysłowe. Jednocześnie w swoich zamierzeniach władze chciały nie tylko doprowadzić do skoku modernizacyjnego, ale również podnieść standard życia ludności, co wiązało się z przeznaczeniem większych środków na konsumpcje i przemysły produkujące dobra konsumpcyjne.

Idea nowej koncepcji industrializacyjnej opierała się na założeniu, że nowe lub modernizowane przedsiębiorstwa, wykorzystując nowoczesne technologie i urządzenia, będą w stanie eksportować swoje towary na Zachód, co stanie się źródłem kapitału niezbędnego do obsługi zadłużenia i spłaty zaciagniętych kredytów (zasada „samospłacenia kredytów”). W oparciu o te założenia uruchomiono w pierwszej połowie lat siedemdziesiatych XX w. szereg nowych projektów przemysłowych, których skala daleko przewyższała rozmiary inwestycji realizowanych od czasu gwałtownej industrializacji w pierwszej połowie lat pięćdziesiątych.

\section{Skala wydatków inwestycyjnych i sposób ich finansowania}

Wprowadzenie programu harmonijnego rozwoju na poczatku lat siedemdziesiątych XX w. przez ekipę Gierka wiązało się ze znacznym wzrostem wydatków inwestycyjnych, spośród których największa kwota została przeznaczona na modernizację przemysłu. Szybki wzrost inwestycji dokonywał się przez większość omawianego okresu, przy czym szczególnie szybko inwestycje rosły w pierwszej połowie lat siedemdziesiatych, podczas gdy pod koniec dekady ich przyrost wyraźnie wyhamował. Realny wzrost znaczenia wydatków na modernizację gospodarki oddaje udział nakładów na środki trwałe i inwestycji $\mathrm{w}$ dochodzie narodowym $\mathrm{w}$ poszczególnych latach. Od początku lat siedemdziesiątych udział ten wyraźnie wzrósł, osiagając w połowie dekady odpowiednio ponad $27 \%$ i ponad $35 \%$. Odsetek ten zaczą powoli spadać od 1976 r. aż do końca lat siedemdziesiątych, przy czym głębokie załamanie nastapiło w $1979 \mathrm{r.}^{21}$

Wpłynęło to na wysoką dynamikę corocznego wzrostu wydatków inwestycyjnych (w cenach stałych) w latach siedemdziesiątych (zob. rys. 2). Zaprezentowane dane ukazuja boom inwestycyjny w pierwszej połowie lat siedemdziesiątych w Polsce, przede wszystkim w latach 1972-1975, a następnie spowolnienie i załamanie pod koniec dekady. Szybki wzrost wydatków inwestycyjnych w pierwszej połowie lat siedemdziesiątych był związany z wprowadzeniem nowego programu gospodarczego mającego poprzez budowę nowych przedsiębiorstw i modernizację istniejących doprowadzić do zamknięcia luki

${ }^{21}$ Idem, East-West Technology Transfer. Study of Poland, 1971-1980, Paris 1983, s. 153. 


\section{Rysunek 2. Stopa wzrostu nakładów inwestycyjnych (ceny stałe 1977, w procentach)}

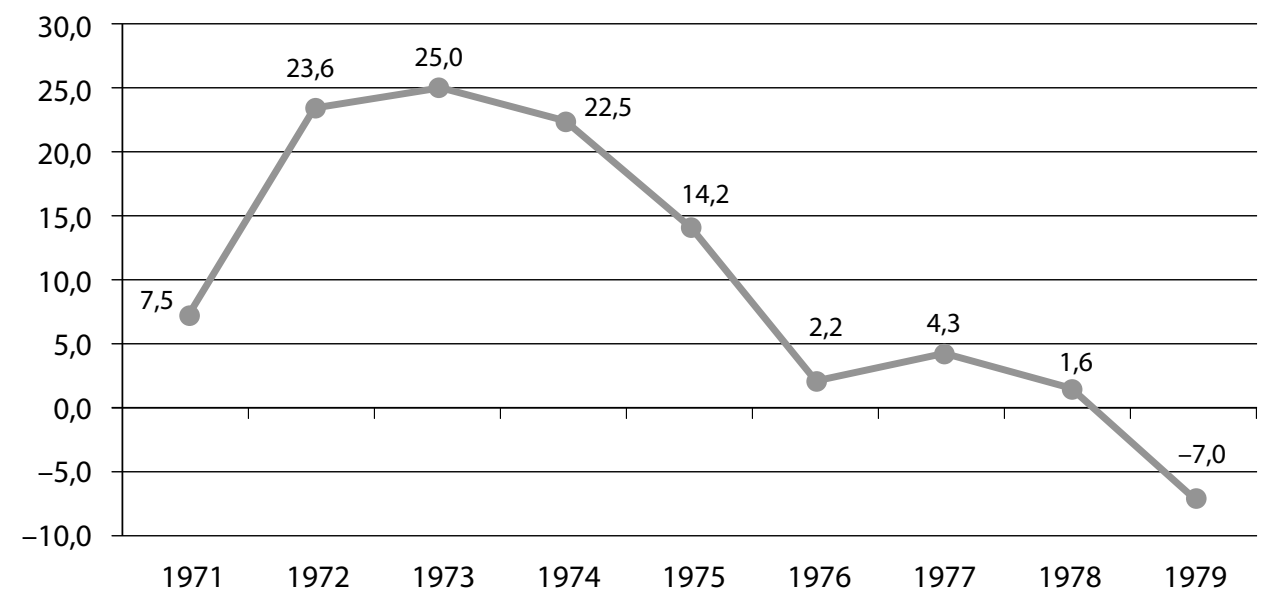

Źródło: Z. Fallenbuchl, East-West Technology Transfer. Study of Poland, 1971-1980, Paris 1983, s. 155.

technologicznej i zmniejszenia dystansu do wysokorozwiniętych gospodarek kapitalistycznych. W ujęciu propagandowym przedstawiano to m.in. jako awans Polski do grona 10 największych gospodarek świata.

Tak duży wysiłek inwestycyjny wymagał znalezienia źródeł finansowania tych wydatków. W gospodarce centralnie planowanej główne źródło inwestycji stanowiła akumulacja kapitału przez państwo, z której finansowano nowe inwestycje. Do 1970 r. większość nowych realizacji była opłacana ze środków wewnętrznych, przy pewnym wsparciu finansowym ZSRS, a inne kapitały zagraniczne odgrywały w procesie inwestycyjnym marginalną rolę. W tych warunkach wzrost wydatków inwestycyjnych musiał się łączyć ze zwiększeniem akumulacji dochodu narodowego, a w konsekwencji ograniczeniem konsumpcji. Pod koniec lat sześćdziesiątych próba wprowadzenia programu selektywnego rozwoju i związane z nią działania prowadzące do ograniczenia konsumpcji (m.in. podwyżki cen żywności) wywołały bunty i strajki, które przyczyniły się do upadku dotychczasowej ekipy Gomułki²2. Nowe władze, starając się zapewnić środki na inwestycje, musiały znaleźć inne źródła finansowania inwestycji, nie mogły pozwolić sobie na działania ograniczające wysokość konsumpcji. Jedynym rozwiązaniem tej sytuacji było skorzystanie z finansowania zewnętrznego - kredytów zaciagniętych zagranicą ${ }^{23}$.

22 Zob. J. Eisler, Grudzień 1970. Geneza, przebieg, konsekwencje, Warszawa 2012.

${ }^{23}$ Z. Fallenbuchl, East-West Technology..., s. 16; zob. też: W. Kuczyński, op. cit., s. 99-106; A. Ząbkiewicz, op. cit., s. 32-33; W. Bień, op. cit., s. 12-13. 
Tabela 1. Zadłużenie zagraniczne Polski długo- i średnioterminowe (w mln zł dewizowych)

\begin{tabular}{|c|c|c|c|c|}
\hline Lata & $\begin{array}{c}\text { W walutach krajów } \\
\text { zachodnich (1) }\end{array}$ & $\begin{array}{c}\text { W walutach krajów } \\
\text { socjalistycznych (2) }\end{array}$ & $\begin{array}{c}\text { Stopa wzrostu } \\
\text { zadłużenia (1) }\end{array}$ & $\begin{array}{c}\text { Stopa wzrostu } \\
\text { zadłużenia (2) }\end{array}$ \\
\hline 1970 & 4149 & 2683 & - & - \\
\hline 1971 & 3921 & 2249 & $-5,50$ & $-16,18$ \\
\hline 1972 & 4586 & 1873 & 16,96 & $-16,72$ \\
\hline 1973 & 8512 & 1059 & 85,61 & $-43,46$ \\
\hline 1974 & 14612 & 425 & 71,66 & $-59,87$ \\
\hline 1975 & 22835 & 1657 & 56,28 & 289,88 \\
\hline 1976 & 33770 & 780 & 47,89 & $-52,93$ \\
\hline 1977 & 42993 & 3684 & 27,31 & 372,31 \\
\hline 1978 & 50662 & 3512 & 17,84 & $-4,67$ \\
\hline 1979 & 62599 & 2867 & 23,56 & $-18,37$ \\
\hline 1980 & 70244 & 2894 & 12,21 & 0,94 \\
\hline 1981 & 74859 & 7559 & 6,57 & 161,20 \\
\hline
\end{tabular}

Źródło: A. Ząbkiewicz, Koncepcja zagranicznej polityki kredytowej w Polsce w latach 1970-1980, Wrocław 1992, s. 150.

Rysunek 3. Stopa wzrostu zadłużenia w walutach zachodnich w latach 1971-1981 (\%)

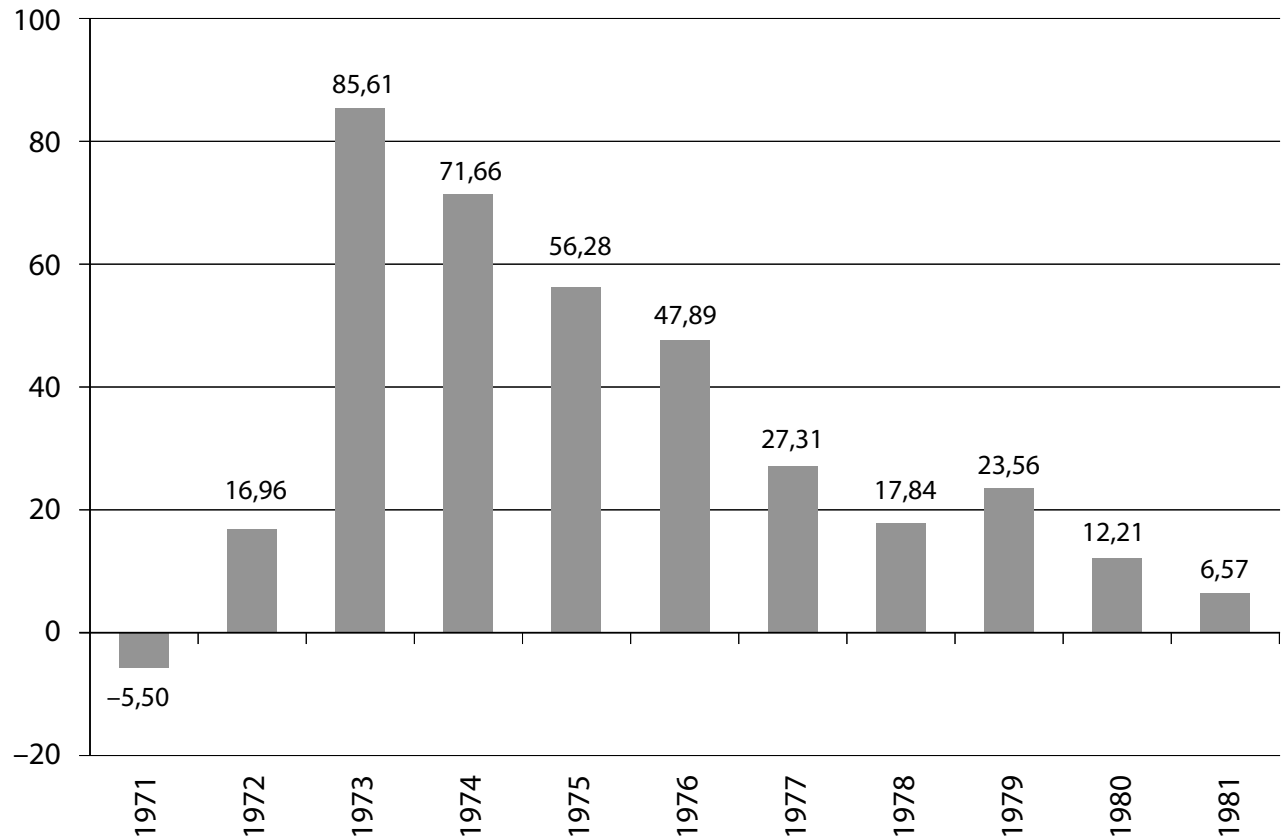

Źródło: A. Ząbkiewicz, Koncepcja zagranicznej polityki kredytowej w Polsce w latach 1970-1980, Wrocław 1992, s. 150. 
Szczególne znaczenie dla sfinansowania modernizacji gospodarki miały pożyczki zaciągane na Zachodzie. $\mathrm{W}$ tab. 1 przedstawione zostały wielkości zadłużenia w latach siedemdziesiątych w krajach kapitalistycznych oraz w krajach zgrupowanych w Radzie Wzajemnej Pomocy Gospodarczej. O ile poziom zobowiązań wobec krajów socjalistycznych pozostawał stosunkowo stabilny i niewielki, o tyle w przypadku krajów zachodnich zadłużenie zaczęło bardzo szybko rosnać od 1972 r., przy czym przyrost tego zadłużenia był szczególnie wysoki pomiędzy 1973 i 1976 r. (odpowiednio 85,6\%, 71,7\%, $56,3 \%$ i 47,9\%). W następnych latach stopa wzrostu długu w walutach zachodnich spadła poniżej 30\%, a w 1981 r. - poniżej 10\% (rys. 3). Zaprezentowane dane odzwierciedlają bardzo wysoki popyt inwestycyjny w pierwszej połowie lat siedemdziesiątych, który ze względu na brak możliwości wewnętrznego finansowania został zaspokojony poprzez zaciąnięcie kredytów zagranicznych.

\section{Struktura wydatków inwestycyjnych}

Program modernizacji gospodarki z pierwszej połowy lat siedemdziesiątych nie miał jednoznacznie sprecyzowanych celów co do lokalizacji i przeznaczenia branżowego. Wręcz przeciwnie, zaproponowane rozwiązanie - zwane strategia „harmonijnego rozwoju” - miało być adresowane do możliwie dużej liczby gałęzi gospodarki. Nowa koncepcja była w zamyśle odpowiedzią na program „selektywnego rozwoju” z końca lat sześćdziesiątych, który adresowano do wybranych dziedzin przemysłu, uznanych za najbardziej perspektywiczne. Polityka ta budziła jednak niechęć znacznej części aparatu gospodarczego, jak i społeczeństwa ${ }^{24}$. W efekcie w latach siedemdziesiątych przydział środków nie miał się koncentrować na rozwoju jakiegoś wybranego regionu kraju ani też - przynajmniej w deklaracjach - preferować żadnej konkretnej branży gospodarki. W praktyce - jak podkreślaja badacze tego okresu - istotne znaczenie w lokowaniu inwestycji w jakimś regionie bądź w poszczególnych gałęziach było konsekwencją siły politycznej władz lokalnych bądź kierowników organizacji gospodarczych.

Omówiony wzrost całkowitych nakładów inwestycyjnych nie rozkładał się równomiernie. Ogólnie w okresie boomu w pierwszej połowie lat siedemdziesiątych najszybciej rosły wydatki w przemyśle i budownictwie, podczas gdy wzrost środków przeznaczanych na skolektywizowane rolnictwo był dużo wolniejszy. Ten trend odwrócił się pod koniec dekady, gdy spadek tempa wzrostu inwestycji najmocniej uderzył w przemysł, a najmniej w rolnictwo (tab. 2).

${ }^{24}$ W. Kuczyński, op. cit., s. 106. 
Tabela 2. Stopa wzrostu nakładów inwestycyjnych (ceny stałe, w procentach)

\begin{tabular}{|l|r|r|r|r|r|r|r|r|r|}
\hline \multicolumn{1}{|c|}{ Rok } & $\mathbf{1 9 7 1}$ & $\mathbf{1 9 7 2}$ & $\mathbf{1 9 7 3}$ & $\mathbf{1 9 7 4}$ & $\mathbf{1 9 7 5}$ & $\mathbf{1 9 7 6}$ & $\mathbf{1 9 7 7}$ & $\mathbf{1 9 7 8}$ & $\mathbf{1 9 7 9}$ \\
\hline Przemysł & 10,4 & 34,6 & 26,7 & 22,2 & 17,0 & 3,0 & $-1,8$ & $-2,1$ & $-15,0$ \\
\hline Budownictwo & $-4,5$ & 38,5 & 79,6 & 26,9 & 7,4 & 3,6 & 10,1 & 1,8 & $-14,3$ \\
\hline Transport i komunikacja & 16,0 & 6,9 & 13,9 & 34,1 & 20,3 & $-14,6$ & $-4,3$ & 5,2 & $-11,3$ \\
\hline Rolnictwo & 4,4 & 14,9 & 17,2 & 18,0 & 16,5 & 2,1 & 14,2 & 0,2 & 0,0 \\
\hline
\end{tabular}

Źródło: Z. Fallenbuchl, East-West Technology Transfer. Study of Poland, 1971-1980, Paris 1983, s. 155.

Rysunek 4. Udział zakładów przemysłowych zbudowanych w latach siedemdziesiątych w wartości środków trwałych w przemyśle w 1985 r. (\%)

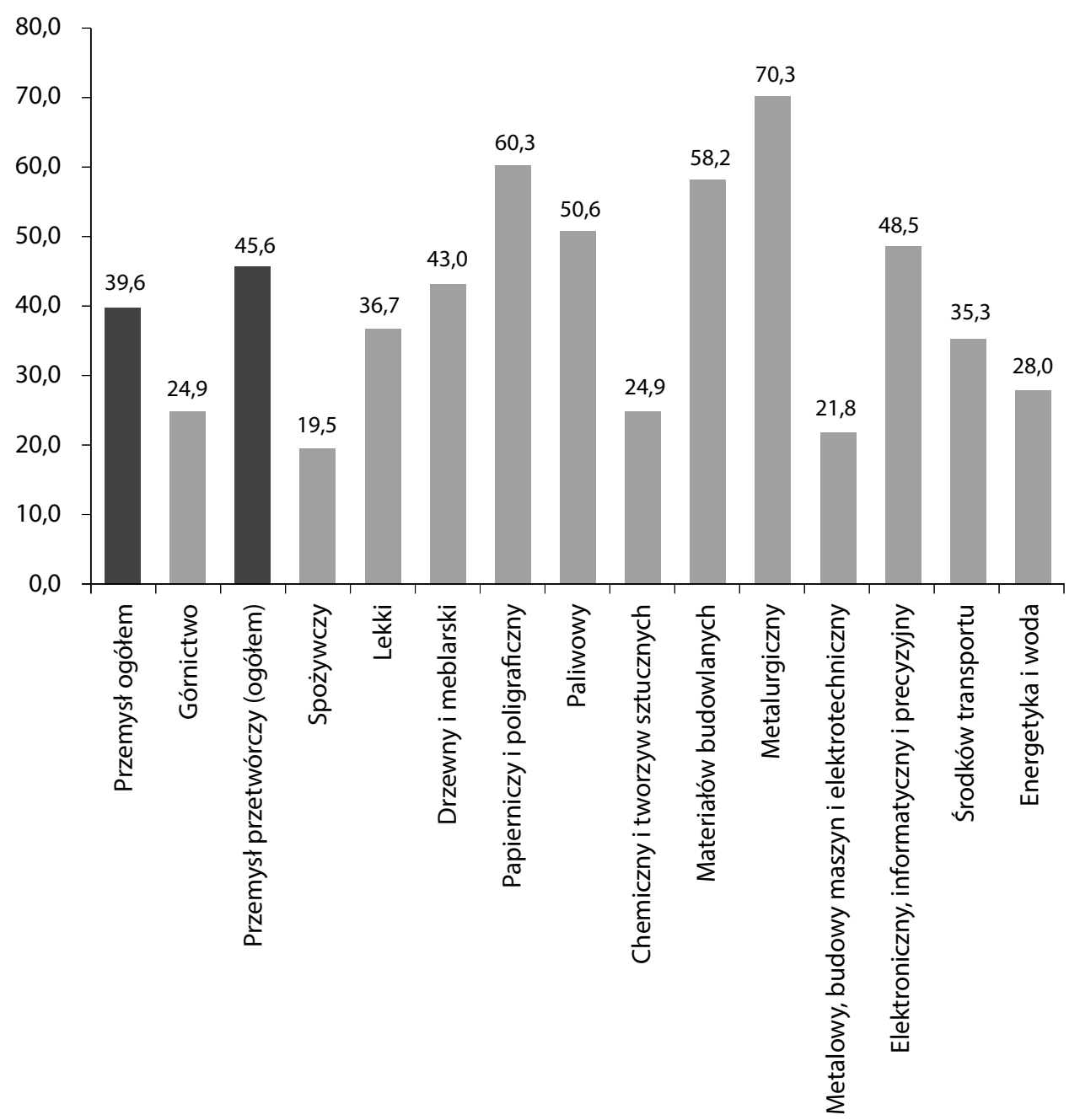

Źródło: A. Karpiński, Drugie uprzemystowienie Polski - prawda czy mit?, w: Dekada Gierka. Wnioski dla obecnego okresu modernizacji Polski, red. K. Rybiński, Warszawa 2011, s. 15. 
Struktura inwestycji przemysłowych oddawała komunistyczny sposób myślenia o rozwoju jako procesie dokonującym się niemal wyłącznie w sferze materialnej. W polityce gospodarczej skutkowało to preferowaniem inwestycji w przemysł ciężki. Największe środki zainwestowano w przemysł metalurgiczny, z flagową realizacja dekady - Hutą Katowice, której przewidywany koszt miał osiagnaćc 25 mld zł, a rzeczywisty - jak sądził Kuczyński - mógł być nawet dziesięciokrotnie większy ${ }^{25}$. Innymi spektakularnymi inwestycjami tego okresu była rozbudowa zagłębia miedziowego na Dolnym Ślasku, budowa rafinerii w Gdańsku, otwarcie fabryki samochodów Fiat w Bielsku i Tychach, wielkiej papierni w Kwidzyniu czy elektrowni i kopalni węgla brunatnego w Bełchatowie. Zainwestowano również w rozbudowę całych gałęzi przemysłu, które bądź wcześniej nie istniały, bądź miały niewielkie znaczenie w gospodarce. Dotyczyło to m.in. przemysłu elektronicznego, w tym zakładów produkujących pierwsze w Polsce komputery przemysłowe ${ }^{26}$. Strukturę wydatków inwestycyjnych lat siedemdziesiątych oddają w znacznym stopniu szacunki Karpińskiego, odnoszące się do udziału zakładów (powstałych w tym okresie) w wartości środków trwałych w przemyśle w 1985 r. (rys. 4). Wskazuja one na zdecydowaną rozbudowę przemysłu metalurgicznego, paliwowego, papierniczego, elektronicznego oraz materiałów budowlanych. Znaczenie tego ostatniego wynika z budowy ok. 110 nowych fabryk domów produkujacych prefabrykaty do budowy wielkich bloków mieszkalnych ${ }^{27}$.

\section{Efekty „drugiego uprzemysłowienia”}

W założeniu program powinien doprowadzić do skoku modernizacyjnego przejawiającego się w szybkim wzroście potencjału gospodarczego państwa. Ten skok miał się dokonać poprzez unowocześnienie przemysłu sfinansowanego w znacznym stopniu kredytami zaciagniętymi zagranica, głównie w krajach kapitalistycznych.

Krótkookresowe efekty prowadzonych inwestycji były imponujące. W pierwszej połowie lat siedemdziesiątych gospodarka Polski rozwijała się zdecydowanie szybciej niż w poprzednich latach, a średnia stopa wzrostu gospodarczego w pierwszej połowie lat siedemdziesiątych przekroczyła 5\% (rys. 5), przewyższając analogiczne wskaźniki w pozostałych krajach bloku komunistycznego ${ }^{28}$. Doprowadziło to do szybkiego wzrostu PKB per capita w okresie realizacji projektów inwestycyjnych.

${ }^{25}$ Ibidem, s. 111.

${ }^{26}$ A. Karpiński, op. cit., s. 15.

${ }^{27}$ Ibidem.

${ }_{28}$ M. Tymiński, Centralnie planowana ucieczka z peryferii. Wzrost gospodarczy Polski na tle Hiszpanii w latach 1950-1975, „Roczniki Dziejów Społecznych i Gospodarczych” 2012, t. LXXII, s. 155-188. 
Rysunek 5. Dynamika wzrostu gospodarczego w Polsce 1971-1990 (\%)

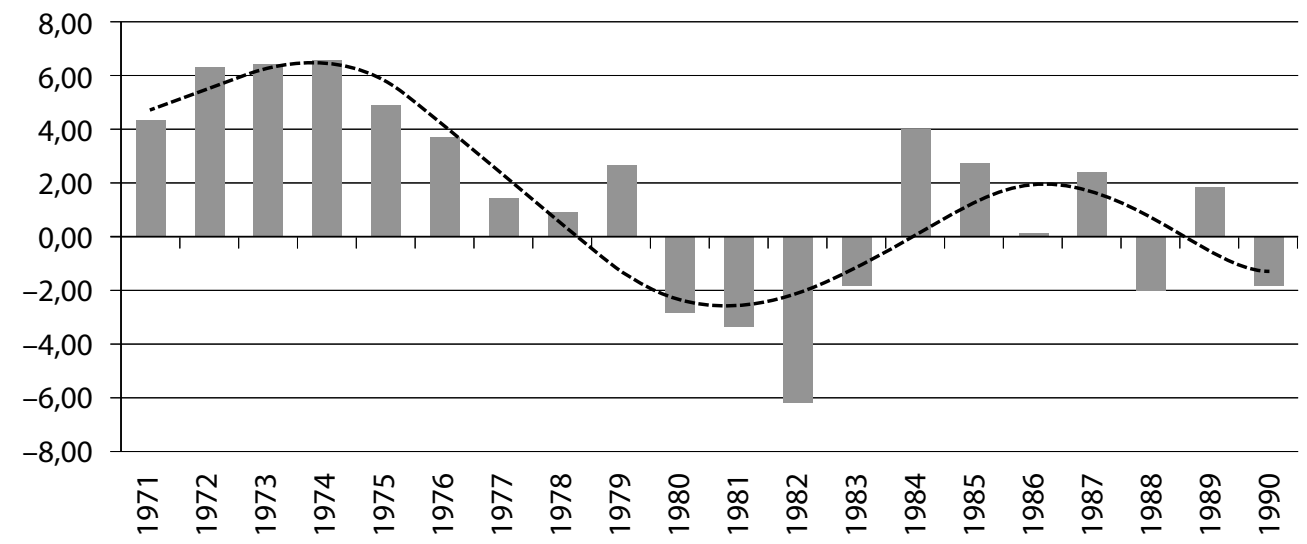

Źródło: Maddison Project, 2013. version 2013, https://www.rug.nl/ggdc/historicaldevelopment/maddison/releases/maddison-project-database-2013 (dostęp: 15 V 2020).

Dzięki prowadzonym inwestycjom oraz zakupom licencji w firmach zachodnich nastapiło odnowienie parku maszynowego. Pozwoliło to na uruchomienie produkcji towarów, wcześniej trudno dostępnych na rynku, chociaż ich jakość była często zdecydowanie niższa od analogicznych produktów na Zachodzie. Według jednego z twórców tego programu polityka prowadzona w latach siedemdziesiątych pozwoliła dokonać skoku modernizacyjnego nie tylko w sferze gospodarczej, ale również społecznej i kulturowej ${ }^{29}$. Jednym z najbardziej spektakularnych, a zarazem widocznych skutków boomu inwestycyjnego w przemyśle było rozpoczęcie produkcji Fiata 126, który był pierwszym samochodem masowo dostępnym dla średnio sytuowanych rodzin w PRL. Inny sukces nowego programu stanowiło otwarcie zakładów materiałów budowlanych (tzw. fabryk domów), dzięki którym w latach siedemdziesiątych znacznie przekroczono liczbę 200 tys. mieszkań budowanych $\mathrm{w}$ ciagu roku ${ }^{30}$. Ważnym osiagnięciem władz w latach siedemdziesiątych było stworzenie ok. miliona nowych miejsc pracy, co zapewniło zatrudnienie dla wchodzącego na rynek w tym okresie pokolenia wyżu demograficznego, urodzonego w latach bezpośrednio po II wojnie światowej ${ }^{31}$.

Niemniej te sukcesy odniesione głównie w pierwszej połowie lat siedemdziesiątych okazały się krótkotrwałe. Już w 1975 r. pojawiły się wyraźne oznaki spowolnienia, które pod koniec dekady przerodziły się w stagnację, a następnie głęboki kryzys (rys. 5). Spowodował on powiększenie się luki

\footnotetext{
${ }^{29}$ P. Bożyk, op. cit., s. 7-10.

${ }^{30}$ C. Bywalec, Wzrost gospodarczy a przemiany poziomu życia społeczeństwa polskiego $w$ latach 1945-1980, Kraków 1986, s. 129-136.
}

${ }^{31}$ A. Karpiński, op. cit., s. 16. 
rozwojowej pomiędzy Polską a Zachodem. O ile w połowie lat siedemdziesiątych polskie PKB per capita stanowiło niecała połowę niemieckiego, to pod koniec lat osiemdziesiątych odsetek ten spadł do ok. 30\%. Wzrost gospodarczy, jeśli w ogóle występował, był niższy nie tylko od analogicznego wskaźnika w krajach kapitalistycznych, ale również od jego wielkości w pozostałych krajach regionu.

Przyczyny załamania gospodarki miały różne źródła, zarówno wewnętrzne, jak i zewnętrzne. Zewnętrzne to przede wszystkim wzrost stopy procentowej kredytów zaciaganych na Zachodzie i utrudniony dostęp do nowych pożyczek, stanowiące wynik kryzysu naftowego i załamania gospodarki światowej w połowie lat siedemdziesiątych. Jednak istotniejsze były przyczyny wewnętrzne zła struktura inwestycji, nadmierne rozmiary wydatków oraz rosnacy popyt inwestycyjny ze strony przedsiębiorstw czy całych branż gospodarki, będący rezultatem charakteru systemu centralnego planowania.

Jedno z założeń programu wprowadzanego w latach siedemdziesiątych to samospłacanie się realizowanych inwestycji. Produkcja z nowych lub modernizowanych przedsiębiorstw miała posłużyć do finansowania spłaty zaciagniętych kredytów. W rzeczywistości struktura realizowanych inwestycji uniemożliwiła takie rozwiązanie. Produkcja polskiego przemysłu nie odpowiadała na potrzeby rynków zagranicznych, a ich niższa jakość utrudniała ich eksport na Zachód ${ }^{32}$. W efekcie pomimo zakończenia części inwestycji bilans płatniczy z zagranica pozostawał ujemny (rys. 6), co powiększało zadłużenie kraju i koszty obsługi zaciagniętych kredytów.

\section{Rysunek 6. Bilans obrotów Polski z krajami kapitalistycznymi (mln zł dewizowych)}

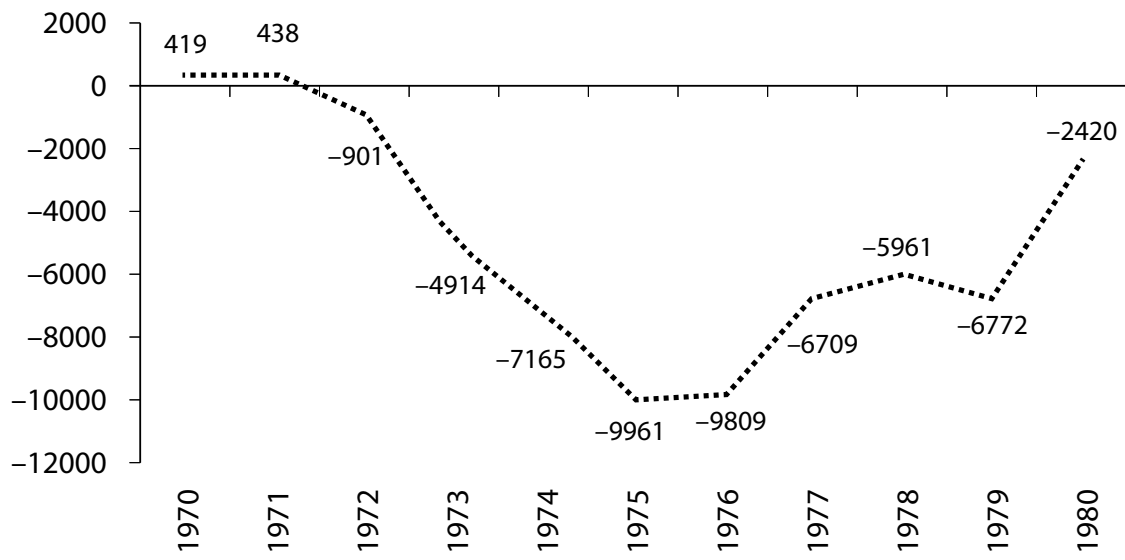

Źródło: A. Ząbkiewicz, Koncepcja zagranicznej polityki kredytowej w Polsce w latach 1970-1980, Wrocław 1992, s. 151.

${ }^{32}$ Zob. Z. Fallenbuchl, East-West Technology..., s. 15; A. Ząbkiewicz, op. cit., s. 40-46, 52-58. 
Zła struktura inwestycji wpływała również na wewnętrzną sytuacje gospodarki. Nadmierne wydatki w przemysł ciężki spowodowały wzrost kapitałochłonności produkcji oraz większe zapotrzebowanie na energię. Łatwy dostęp do funduszy przejawił się w zbyt dużej liczbie otwieranych projektów. Wobec dużej liczby nowych projektów moce produkcyjne gospodarki były daleko niewystarczające (zarówno w sferze logistycznej, jak i wykonawczej). W efekcie znaczna część inwestycji pozostała niezakończona, a realizacja innych przeciagnęła się w czasie i pochłonęła większe środki od zaplanowanych. Spadek finansowania inwestycji od $1977 \mathrm{r}$. wywołał gwałtowne obcięcie funduszy na realizowane zadania, co spowodowało spadek wskaźnika ukończonych inwestycji począwszy od $1978 \mathrm{r}$. W dodatku władze zamiast dokonać realokacji i racjonalizacji nakładów do lepiej rokujących przedsięwzięć, wydłużyły czas wykonania realizowanych projektów. W rezultacie wraz z trudniejszym dostępem do nowych kredytów wielu projektów nie zakończono jeszcze w połowie lat osiemdziesiatych ${ }^{33}$.

Możliwe, że najważniejszą przyczynę załamania programu władz stanowił rosnacy popyt inwestycyjny ze strony przedsiębiorstw i poszczególnych gałęzi przemysłu. Był to efekt miękkiego ograniczenia budżetowego występującego $\mathrm{w}$ gospodarkach centralnie planowanych ${ }^{34}$. Przedsiębiorstwa, zjednoczenia przemysłowe i ministerstwa zgłaszały w ramach negocjacji ze swoimi władzami bardzo wysokie zapotrzebowanie na środki inwestycyjne, jednocześnie starając się ograniczyć wielkość zadań wyznaczanych w planie. Proces dostosowań dokonywał się $\mathrm{w}$ trakcie tzw. przetargu planistycznego ${ }^{35}$, podczas którego ustalano ostateczną wielkość środków na cele inwestycyjne.

W rezultacie - jak pokazuja badania Joanny Kotowicz-Jawor ${ }^{36}$ - wielkość popytu zgłaszanego przez ministerstwa była niemal zawsze wyższa od proponowanych we wstępnym planie, a kwoty faktycznie przeznaczane na inwestycje wzrastały z reguły znacznie powyżej wstępnie planowanych (tab. 3). Proces ten miał miejsce na wszystkich szczeblach scentralizowanej hierarchii zarządzania gospodarka - pomiędzy władzami centralnymi a ministerstwami, ministerstwami a zjednoczeniami i zjednoczeniami a przedsiębiorstwami. W konsekwencji zwycięzcami byli ci, którzy posiadali największą siłę polityczną (przemysł ciężki, regiony ważne politycznie, np. Ślassk), co z reguły nie wiązało się z inwestycjami najbardziej efektywnymi z punktu widzenia

${ }^{33}$ Poland. Reform, Adjustment, and Growth, t. I: The Main Report, the Economic System, Washington 1987, s. 40-41.

${ }^{34}$ J. Kornai, Economics of Shortage, Amsterdam 1980; idem, The Socialist System. The Political Economy of Communism, Princeton 1992.

35 E. Balcerowicz, Przetarg planistyczny. Mechanizmy i skutki społeczno-gospodarcze, Warszawa 1991.

36 J. Kotowicz-Jawor, Nadmierna skłonność do planowania w świetle polskiego doświadczenia planistycznego, „Prace Instytutu Planowania” 1979, nr 60, s. 5-94; eadem, Presja inwestycyjna w latach siedemdziesiatych, Warszawa 1983. 
Tabela 3. Relacja pomiędzy zgłaszanym popytem na środki inwestycyjne (a) a pierwotną wersją planu (p) i faktycznie poniesionymi nakładami (r) w latach 1970-1975 (w \%)

\begin{tabular}{|c|c|c|c|c|c|c|c|}
\hline \multicolumn{1}{|c|}{ Ministerstwo } & Relacja & $\mathbf{1 9 7 0}$ & $\mathbf{1 9 7 1}$ & $\mathbf{1 9 7 2}$ & $\mathbf{1 9 7 3}$ & $\mathbf{1 9 7 4}$ & $\mathbf{1 9 7 5}$ \\
\hline \multirow{2}{*}{ Przemysł maszynowy } & $\mathrm{a} / \mathrm{p}$ & 122,2 & 106,2 & 109,6 & 113,3 & 149,2 & 114,3 \\
\cline { 2 - 8 } & $\mathrm{a} / \mathrm{r}$ & 122,2 & 108,9 & 101,5 & 93,5 & 124,2 & 104,0 \\
\hline \multirow{2}{*}{ Przemysł ciężki } & $\mathrm{a} / \mathrm{p}$ & 118,0 & - & 112,1 & 100,0 & 111,6 & 134,5 \\
\cline { 2 - 8 } & $\mathrm{a} / \mathrm{r}$ & 124,7 & 99,7 & 91,9 & 79,6 & 105,6 & 108,5 \\
\hline \multirow{2}{*}{ Przemysł lekki } & $\mathrm{a} / \mathrm{p}$ & 125,0 & 111,2 & 113,2 & 98,5 & 123,1 & 121,3 \\
\cline { 2 - 8 } & $\mathrm{a} / \mathrm{r}$ & 131,9 & 101,0 & 102,0 & 84,7 & 122,4 & 131,0 \\
\hline
\end{tabular}

Źródło: J. Kotowicz-Jawor, Presja inwestycyjna w latach siedemdziesiatych, Warszawa 1983, s. 131.

gospodarki. Wadliwy system podejmowania decyzji w gospodarce planowej miał w efekcie negatywny wpływ na strukturę wydatków inwestycyjnych oraz powodował wzrost ich wielkości.

Ostateczny efekt wprowadzenia polityki „harmonijnego rozwoju” czy też „drugiego uprzemysłowienia Polski” był zdecydowanie negatywny. Istotę niepowodzenia tego projektu oddają dane przywołane przez Kuczyńskiego ${ }^{37}$. Rzeczywiste wydatki inwestycyjne podniosły się o ponad 90\%, gdy planowany wzrost był dwukrotnie mniejszy. Zwiększone względem planu wydatki tylko częściowo stanowiły efekt planowanego manewru gospodarczego, w znacznej części odpowiadał za nie rosnący popyt inwestycyjny zgłaszany przez branże i przedsiębiorstwa. Jednocześnie wyższa dynamika inwestycji w porównaniu ze wzrostem dochodu narodowego (69\% w latach 1971-1975) wskazuje na ograniczona efektywność nowych realizacji. Oznacza to, że już w pierwszej połowie lat siedemdziesiątych, okresie szybkiego wzrostu inwestycji i dobrej koniunktury, wyraźne były przesłanki zbliżającej się porażki. Długookresowo boom inwestycyjny lat siedemdziesiątych spowodował relatywny spadek PKB per capita i dynamiki wzrostu gospodarczego w porównaniu nie tylko z Zachodem, ale również w zestawieniu z państwami socjalistycznymi. Kryzys wywołany polityką z lat siedemdziesiątych przejawił się głębokim załamaniem gospodarki, obniżeniem poziomu życia i wysoką inflacją w latach osiemdziesiątych.

\section{Analiza porównawcza}

Poziom nakładów inwestycyjnych w PRL od 1946 do 1977 stale rósł, co pokazano na rys. 7. Pomiędzy 1946 a 1977 r. roczne nakłady na inwestycje wzrosły ponad 33-krotnie, a od $1950 \mathrm{r}$. rozpoczynającego plan 6-letni - niemal 15-krotnie. Co więcej, od 1970 do 1977 r. roczne nakłady inwestycyjne wzrosły

${ }^{37}$ W. Kuczyński, op. cit., s. 100. 
2,5 razy, co odpowiadało dynamice osiaganej od końca lat czterdziestych do 1956 r. Po 1977 r. nadszedł okres gwałtownego załamania, a wydatki inwestycyjne przez koleje lata zmniejszały się, by w 1982 r. spaść do poziomu 53\% maksimum (i poziomu osiagniętego dokładnie dekadę wcześniej). Po wzroście przez następne lata, do 1988 r. nakłady inwestycyjne doszły do poziomu niewiele niższego niż w $1974 \mathrm{r}$.

Rysunek 7. Poziom inwestycji (ceny stałe, 1984) i PKB (ceny stałe, 1990) w PRL (indeks, rok $1950=100)$

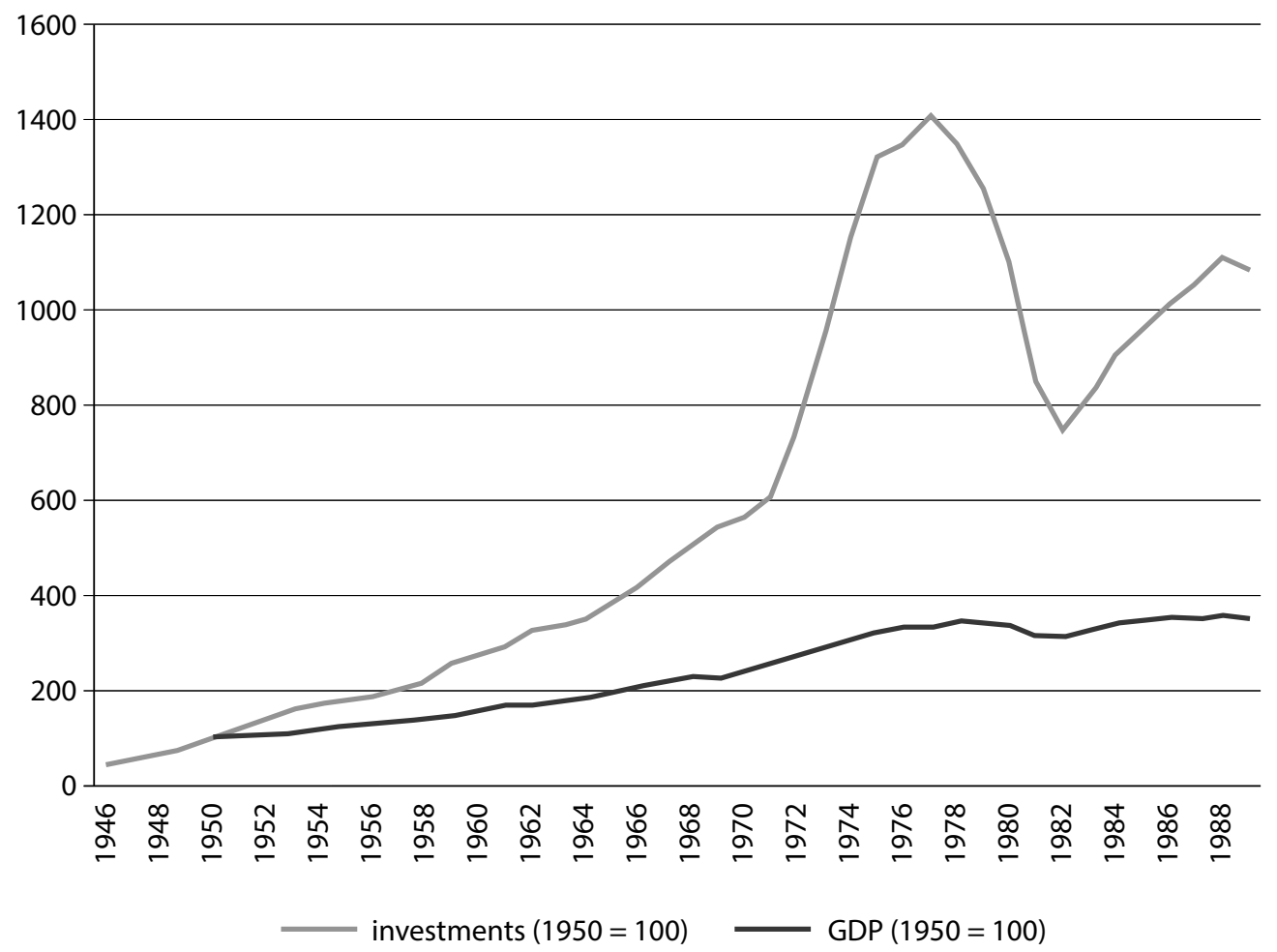

Źródło: Rys. 1; Maddison Project, 2013. version 2013, https://www.rug.nl/ggdc/historicaldevelopment/ maddison/releases/maddison-project-database-2013 (dostęp: $15 \mathrm{~V}$ 2020).

Wyjątkowość cyklu w okresie rządów Gierka polega zarówno na dynamice wzrostu inwestycji (co można porównać tylko z okresem odbudowy), jak i skali późniejszego załamania. Pomiędzy 1973 a 1981 r. dynamika przyrostu nakładów inwestycyjnych spadła z przeszło $20 \%$ wzrostu $\mathrm{r} / \mathrm{r}$ do przeszło $20 \%$ spadku r/r. Początkowe siedem lat w cyklu gierkowskim przypominało cykl powojenny. Przyrost nakładów w porównaniu z rokiem wyjściowym był podobny odpowiednio do 1956 i 1977 r. Spowolnienie związane z zawirowaniami społeczno-gospodarczymi (1954-1956) kulminowało przejęciem władzy przez Gomułkę 
w październiku 1956 i powiewem optymizmu w społeczeństwie, a także ponownym wzrostem dynamiki nakładów inwestycyjnych i ich stabilizacja na poziomie wzrostu ok. $10 \% \mathrm{r} / \mathrm{r}$. Spowolnienie z połowy lat siedemdziesiątych również przyniosło falę społecznego niezadowolenia (z kulminacją w czerwcu 1976), ale nie poskutkowało zmianą władz i modelu polityki gospodarczej. W przeciwieństwie do lat pięćdziesiątych od 1977 r. sytuacja gospodarcza Polski ulegała dalszemu pogorszeniu przez kolejne lata i została ustabilizowana przy niemal zerowym wzroście gospodarczym dopiero na początku lat osiemdziesiątych. Podobnie inwestycje zaczęły wzrastać dopiero po $1981 \mathrm{r}$.

Przed rozważeniem powodów skali tego załamania warto jednak wskazać na podobieństwa pierwszych faz obydwu cykli. O ile okres powojennej odbudowy (1946-1949) był wyjątkowy, ponieważ skala zniszczeń wymuszała zarówno rozmiary, jak i dynamikę nakładów inwestycyjnych, o tyle okres stalinowskiej modernizacji cechował się próbą dokonania skoku rozwojowego w oparciu o wymuszoną akumulację i wsparcie ZSRS. Wysoka dynamika nakładów inwestycyjnych miała swoje źródła w szybkiej industrializacji realizowanej w oparciu o importowane sowieckie technologie. Jej sztandarowym przykładem stała się Nowa Huta w Krakowie, ale nowe inwestycje urzeczywistniano także w wielu innych miejscach (m.in. Fabryka Samochodów Osobowych w Warszawie).

Projekt gierkowski nawiązywał do tej strategii (wielu jego wykonawców rozpoczynało kariery właśnie $\mathrm{w}$ okresie stalinowskim) - nie wprost, ale w modelu rozwoju. Więcej uwagi poświęcano przemysłom dóbr konsumpcyjnych, a sama skala inwestycji była nieporównanie większa. Jednak znów kołem zamachowym rozwoju stała się pospieszna industrializacja $\mathrm{w}$ oparciu o importowane technologie. Ponownie sztandarowe projekty dotyczyły przemysłu ciężkiego (na czele z Hutą Katowice) i samochodowego (Fabryka Samochodów Małolitrażowych w Tychach i Bielsku-Białej).

Przejęcie władzy przez Gomułkę i reorientacja polityki gospodarczej w 1956 r. pozwoliły uniknać głębokiego załamania po okresie nadmiernej ekspansji inwestycyjnej. Gospodarka Polski wciąż jeszcze była na względnie niskim poziomie kapitałochłonności, a pomimo ekspansji fiskalnej planu 6-letniego skala inwestycji okazała się wielokrotnie niższa (w cenach stałych) niż w czasach gierkowskich. Również w odbudowanej po zniszczeniach wojennych gospodarce, dopiero stającej się przemysłowa, koszty inwestycji odtworzeniowych i remontów były względnie niewielkie w porównaniu ze skala wszystkich wydatków inwestycyjnych. W dodatku skala uzależnienia polskiej gospodarki od eksportu była bardzo niska, podobnie jak poziom zadłużenia. To pozwoliło dość łagodnie przejść kryzys przeinwestowania i ustabilizować wzrost środków inwestycyjnych na poziomie ok. 10\%. Taka strategia zapewniła względnie stabilny, choć niezbyt dynamiczny rozwój przez ok. dekadę. $\mathrm{W}$ tym okresie kończono nie w pełni zrealizowane inwestycje z okresu planu 6-letniego, a gospodarka dostosowywała się do nowych warunków działania 
z szybko rozbudowanym sektorem przemysłowym. Wyczerpanie tego modelu i próba kolejnego manewru gospodarczego pod koniec lat sześćdziesiątych (program selektywnego rozwoju) nie powiodły się.

Tak jak w połowie lat pięćdziesiątych załamał się model intensywnej industrializacji, tak w $1976 \mathrm{r}$. wyczerpał się model modernizacji wprowadzony przez ekipę Gierka, czego bezpośrednim przejawem była konieczność dostosowania cen. Wywołało to falę protestów społecznych (Radom, Ursus), ale tym razem nie doszło do zmiany władzy ani reorientacji polityki gospodarczej. Wyhamowanie, a potem gwałtowny spadek nakładów inwestycyjnych doprowadziły do wstrzymania i niedokończenia wielu projektów, a istotna część poniesionych w pierwszej połowie dekady nakładów okazała się utopiona i niemożliwa do odzyskania.

Zestawienie nakładów inwestycyjnych i dynamiki PKB (rys. 7) pokazuje, że kapitałochłonność polskiej gospodarki rosła, a wzrost inwestycji w coraz mniejszym stopniu przekładał się na wzrost PKB. Dwukrotnemu wzrostowi inwestycji pomiędzy 1950 (pierwszym, dla którego sa powojenne szacunki PKB) i 1957 r. towarzyszył wzrost PKB o 40\%. Niemal 2,5-krotny wzrost inwestycji w latach 1971-1975 wystapił przy wzroście PKB o $35 \%$ (i jeszcze mniejszym wzroście PKB per capita). W drugiej połowie lat siedemdziesiątych spadkowi inwestycji o 40\% towarzyszył spadek PKB o 15\%, zaś wolny wzrost inwestycji pomiędzy 1982 i 1988 (o 50\%) związany był z bardzo nieznacznym wzrostem PKB o $12 \%$.

Inwestycje z upływem lat dawały coraz słabszy bodziec do wzrostu. Wiazało się to zapewne z tym, że w coraz większym stopniu miały odtworzeniowy charakter (choć niestety zmiany sposobu prezentacji danych uniemożliwiaja wyczerpujace potwierdzenie tej hipotezy). Od 1960 do 1971 r. udział inwestycji odtworzeniowych w łącznej sumie inwestycji wzrósł z 18 do $22 \%$, potem w okresie gierkowskiej ekspansji spadł do 16\% (1973). Niestety dane z kolejnych lat są nieporównywalne. Sądzić należy jednak, że od 1977 r. udział inwestycji odtworzeniowych szybko rósł.

Po gwałtownym „skoku” poziomu inwestycji równie szybko nastapił spadek. W długim okresie dynamika rocznego poziomu inwestycji pozostawała $\mathrm{w}$ trendzie liniowym, a załamanie $\mathrm{z}$ drugiej połowy lat siedemdziesiątych można interpretować jako powrót do tego trendu. Ostatnia w PRL i najpoważniejsza próba modernizacji rozumianej jako dążenie do zmiany długookresowych trendów rozwojowych zakończyła się kompletnym niepowodzeniem.

\section{Konkluzje}

Przeprowadzona analiza wydatków inwestycyjnych w ramach programu industrializacji z lat siedemdziesiątych pozwala na sformułowanie wniosków dotyczących jego efektywności. Inwestycje realizowane w okresie rządów 
Gierka poskutkowały znacznym przyrostem kapitału trwałego w gospodarce, jednak zarówno nadmierny poziom inwestycji, ich struktura gałęziowa, jak i przestrzenna alokacja utrudniły lub uniemożliwiły efektywne wykorzystanie tego kapitału. Dynamika wzrostu PKB była dużo wolniejsza niż wzrostu inwestycji, a wzrost produktywności w przemyśle właściwie nie występował. Oczekiwane korzyści z programu inwestycyjnego okazały się ograniczone. Dotyczyło to również wzrostu eksportu, który miał umożliwić spłatę kredytów.

Nieefektywność polityki gospodarczej, a w szczególności alokacji inwestycji doprowadziła do kryzysu gospodarczego. Załamanie, którego wczesnym objawem było wyhamowanie wzrostu nakładów inwestycyjnych, zaczęło się w połowie dekady i trwało do początku lat osiemdziesiątych. Później, aż do upadku systemu komunistycznego w 1989 r., gospodarka pozostawała w stagnacji. Wzrost gospodarczy już nie powrócił do poziomów obserwowanych w pierwszej połowie lat siedemdziesiątych ani nawet do wielkości z lat sześćdziesiątych. Krótkookresowo polityka gospodarcza Gierka doprowadziła do poprawy standardu życia, a utworzenie nowych miejsc pracy pozwoliło na zaabsorbowanie na rynku pracy pokolenia wyżu demograficznego. Okres szybkiego wzrostu nakładów inwestycyjnych w dłuższej perspektywie został przerwany gwałtownym i długookresowym spadkiem poziomu inwestycji (od 1977). W efekcie wpływ programu na unowocześnienie gospodarki i przyspieszenie procesu doganiania gospodarek wysokorozwiniętych był jedynie krótkookresowy.

Niepowodzenie gierkowskiej polityki inwestycyjnej miało, podobnie jak w przypadku wcześniejszych komunistycznych wysiłków inwestycyjnych, kilka źródeł. Jednak szczególnie istotny stał się nieefektywny proces podejmowania decyzji inwestycyjnych. Był to proces zagmatwany i silnie uzależniony od gry różnych grup interesów, zarówno regionalnych, jak i branżowych ${ }^{38}$. Wprawdzie centralny ośrodek decyzyjny znajdował się w Biurze Politycznym Komitetu Centralnego PZPR i rządzie, ale w rzeczywistości decyzje o wielkości i lokalizacji inwestycji rozkładały się pomiędzy ośrodki władzy na różnych szczeblach aparatu partyjno-państwowego, co przejawiało się $\mathrm{w}$ rosnącym popycie inwestycyjnym i realizacji inwestycji w wymiarze daleko przekraczajacym pierwotne plany ${ }^{39}$. Alokacja funduszy inwestycyjnych, będąca rezultatem rosnacej siły przetargowej komunistycznych menadżerów i lokalnych aparatczyków partyjnych względem słabnącego centrum, przyczyniła się do nieefektywności procesu inwestycyjnego. Wydaje się, że dość wcześnie instytucje centralne utraciły rzeczywistą zdolność do zarządzania procesami inwestycyjnymi i w coraz większym stopniu zajmowały się jedynie dystrybucja pozyskiwanych z zagranicy środków - w efekcie realizacja celów programu stała się zupełnie niemożliwa ${ }^{40}$.

\footnotetext{
${ }^{38}$ Zob. K. Dąbek, PZPR - retrospektywny portret wtasny, Warszawa 2006.

${ }^{39}$ Zob. J. Kotowicz-Jawor, Presja inwestycyjna..., s. 115-146.

${ }^{40}$ W. Kuczyński, op. cit., s. 122-123.
} 
W PRL polityka inwestycyjna pełniła funkcje zarówno gospodarcze, jak i polityczno-społeczne. Brak bodźców rynkowych utrudniał lub wręcz uniemożliwiał racjonalne gospodarowanie. W rezultacie cykle inwestycyjne związane były z cyklem politycznym $\mathrm{w}$ dużo większym stopniu niż $\mathrm{w}$ gospodarkach kapitalistycznych. Wysiłki inwestycyjne prowadziły do narastania braku równowagi w gospodarce, szybko skutkującej pogorszeniem się sytuacji ekonomicznej obywateli i protestami. Ze względu na to, że właścicielem niemal wszystkich zasobów i dóbr trwałych w gospodarce było państwo, odczuwało ono konsekwencje zarówno błędów polityki inwestycyjnej, jak i gwałtownych oraz nieprzemyślanych działań majacych uspokajać nastroje. W efekcie polityka inwestycyjna miała silnie procykliczny charakter, a najbardziej widomy tego przykład stanowiła polityka Gierka. Taki charakter polityki gospodarczej powodował narastanie napięć w kolejnych cyklach. W wypadku Gierka kluczowe było rosnące zadłużenie. Dość długo tego ryzyka unikała ekipa Gomułki, na co wpłynęły ostrożniejsza polityka inwestycyjna (w porównaniu z intensywną industrializacją lat pięćdziesiątych i późniejszymi działaniami Gierka) i ograniczone możliwości finansowania nowych projektów (przy niechęci Gomułki do zwiększania zadłużenia państwa i wyczerpujących się źródłach wewnętrznych). Jednak relatywnie powolny rozwój przekładał się na powolny wzrost standardu życia, co prowadziło do narastania społecznego niezadowolenia. W efekcie pomimo ostrożnej polityki inwestycyjnej i rozwojowej w porównaniu z okresem poprzedzającym „małą stabilizację”, jak i po niej następującego, i tak skończyła się ona falą protestów.

Wydaje się więc, że w warunkach gospodarki nakazowej trudno wskazać lepsze strategie polityki inwestycyjnej niż jej cykliczne zrywy. W okresach kryzysu niezadowolenie społeczne koncentrowało się na jedynym właścicielu i zarządcy - władzach partyjno-państwowych, a najlepszą strategia pacyfikacji protestów była pospieszna ekspansja inwestycyjna. Okazja, jaka stało się zbliżenie z Zachodem w warunkach trwałej recesji tamże, sprawiła, że skala nowej ekspansji inwestycyjnej mogła być większa niż wcześniej. Model gospodarczo-polityczny, w którym brakowało jakichkolwiek zabezpieczeń przed nieracjonalną polityką gospodarcza, przyczynił się zaś zarówno do nadmiernej skali, jak i nieracjonalności wydatków.

Zdaje się, że stalinowski model przyspieszonej akumulacji wyczerpał możliwości ekspansji inwestycyjnej w oparciu o wewnętrzne zasoby. Po 1956 r. brakowało już wystarczająco silnego aparatu przymusu, wiary aparatczyków w sukces i skłonności do zaryzykowania takiego modelu rozwoju raz jeszcze. Próba wprowadzenia tzw. programu selektywnego rozwoju, opartego na finansowaniu wewnętrznym i ograniczeniu konsumpcji, zakończyła się protestami i upadkiem ekipy Gomułki, który nie docenił oporu przed takim rozwiązaniem nie tylko wśród aparatu partyjno-państwowego, ale przede wszystkim wśród robotników wielkich zakładów, obawiajacych się kolejnego obniżenia standardu życia. Z kolei model gierkowskiej modernizacji na długo 
wyczerpał możliwość rozwoju w oparciu o zewnętrzne źródła finansowania. Utrata wypłacalności podważyła zaufanie zagranicznych instytucji finansowych i rządów do Polski. Od tego momentu brakowało już jakichkolwiek źródeł finansowania umożliwiajacych powrót do dynamicznego rozwoju w latach osiemdziesiątych. Po długotrwałej stagnacji zagraniczny kapitał inwestycyjny pojawił się na większą skalę dopiero w latach dziewięćdziesiątych po transformacji systemowej i wprowadzeniu reguł gospodarki rynkowej.

\section{Streszczenie}

W pierwszej połowie lat siedemdziesiątych XX w. pod rządami Edwarda Gierka Polska przechodziła największy w historii boom gospodarczy. Można go potraktować jako próbę gwałtownej modernizacji gospodarki przy jednoczesnym wzroście stopy życiowej ludności. W niniejszym opracowaniu zostały przedstawione podstawowe założenia planu ekipy Gierka, źródła i skala finansowania oraz wyniki realizacji programu rozwoju gospodarki na tle wyników gospodarczych osiagniętych przez wcześniejsze ekipy rządzące w PRL. W realizacji tego programu kluczową rolę odgrywały technologie importowane z krajów wysokorozwiniętych oraz nowe projekty inwestycyjne finansowane z kredytów zaciagniętych na Zachodzie. Autorzy, w oparciu o dane statystyczne pokazuja, że rezultaty modernizacji kraju w latach siedemdziesiątych chociaż spowodowały krótkotrwałe przyspieszenie rozwoju, nie przyniosły oczekiwanych efektów - pomimo nienotowanych wcześniej wydatków na nowe inwestycje produktywność gospodarki nie wzrosła, a nieudolne zarządzanie i realizacja polityki gospodarczej doprowadziły do głębokiego załamania pod koniec dekady. Gierkowski boom gospodarczy, jak i polityki wprowadzane we wcześniejszych okresach wskazuja, że gospodarki nakazowe niezależnie od przyjętej strategii rozwoju nie były w stanie osiagnąć zakładanych rezultatów, a nadmierna ekspansja inwestycyjna kończyła się głębokimi kryzysami gospodarki.

\section{A Wasted Decade? The Investment Expansion of the 1970s against the Background of Economic Policy in People's Poland}

In the first half of the 1970s, under First Secretary Edward Gierek, Poland underwent the greatest 'economic boom' in the history of the Polish People's Republic. It can be seen as an attempt to rapidly modernise the economy, with a simultaneous rise in the population's standard of living. Technologies imported from highly developed countries and new investment projects financed by loans taken from the West played a vital role in implementing this programme. This study presents the basic assumptions of Gierek's team's plan, the sources and scale of its financing, and the results of the programme's implementation for the development of the economy, against the background of the economic results achieved by the previous ruling teams in People's Poland. Based on statistical data, the authors show that the attempts at the modernisation of the country in the 1970s, although they caused a short-term acceleration of development, did not bring the expected results. Despite unprecedented expenditure on new investments, the economy's productivity did not increase, while inept management and implementation of economic policy led to a deep slump at the end of the decade. The 'economic boom' of Gierek's era and the policies implemented in earlier periods indicate that command economies, regardless of the adopted development strategy, could not achieve the expected results, and excessive investment expansion ended in deep economic crises. 


\section{Bibliografia}

Balcerowicz E., Przetarg planistyczny. Mechanizmy i skutki społeczno-gospodarcze, Warszawa 1991.

Bałtowski M., Gospodarka socjalistyczna w Polsce. Geneza - rozwój - upadek, Warszawa 2009.

Bożyk P., Cywilizacyjne skutki „otwarcia” Polski na Zachód, w: Dekada Gierka. Wnioski dla obecnego okresu modernizacji Polski, red. K. Rybiński, Warszawa 2011, s. 5-12.

Bywalec C., Wzrost gospodarczy a przemiany poziomu życia społeczeństwa polskiego w latach 1945-1980, Kraków 1986.

Dąbek K., PZPR - retrospektywny portret wtasny, Warszawa 2006.

Dwilewicz Ł., Polityka selektywnego rozwoju w latach 1968-1970, w: Nauki ekonomiczno-społeczne i rozwój, red. K. Żukrowska, Warszawa 2008, s. 331-352.

Dwilewicz Ł., Reformy Bolestawa Jaszczuka i polityka gospodarcza epoki gierkowskiej, w: Dekada Gierka. Wnioski dla obecnego okresu modernizacji Polski, red. K. Rybiński, Warszawa 2011, s. 73-120.

Eisler J., Grudzień 1970. Geneza, przebieg, konsekwencje, Warszawa 2012.

Fallenbuchl Z., East-West Technology Transfer. Study of Poland, 1971-1980, Paris 1983.

Fallenbuchl Z., Polityka gospodarcza PRL, Londyn 1980.

Grala D., Reformy gospodarcze w PRL (1982-1989), Warszawa 2005.

Jedlicki J., Nieudana próba kapitalistycznej industrializacji. Analiza państwowego gospodarstwa przemystowego w Królestwie Polskim XIX w., Warszawa 1964.

Jezierski A., Petz B., Historia gospodarcza Polski Ludowej 1944-1985, Warszawa 1988.

Jędrychowski S., Zadtużenie Polski w krajach kapitalistycznych, Warszawa 1982.

Kaliński J., Etatyzacja gospodarki w okresie rzadów komunistycznych w Polsce, „Kwartalnik Kolegium Ekonomiczno-Społecznego «Studia i Prace»" 2015, nr 4, s. 177-201.

Kaliński J., Gomutkowskie dylematy modernizacji gospodarki, „Annales Universitatis Paedagogicae Cracoviensis. Studia Politologica" 2011, t. V, s. 41-50.

Karpiński A., Drugie uprzemystowienie Polski - prawda czy mit?, w: Dekada Gierka. Wnioski dla obecnego okresu modernizacji Polski, red. K. Rybiński, Warszawa 2011, s. 13-26.

Karpiński A., Paradysz S., Soroka P., Żółtkowski W., Od uprzemystowienia w PRL do deindustrializacji kraju. Losy zaktadów przemystowych po 1945 roku, Warszawa 2015.

Kornai J., Economics of Shortage, Amsterdam 1980.

Kornai J., The Socialist System. The Political Economy of Communism, Princeton 1992.

Koryś P., Tymiński M., Od socjalizmu do socjalizmu. Koncepcje reform gospodarczych $w$ PRL po wybuchach społecznych w 1956 i 1980 r., „Dzieje Najnowsze” 2016, nr 4, s. 125-140.

Kotowicz-Jawor J., Nadmierna skłonność do inwestowania w świetle polskiego doświadczenia planistycznego, „Prace Instytutu Planowania” 1979, nr 60, s. 5-94.

Kotowicz-Jawor J., Presja inwestycyjna w latach siedemdziesiatych, Warszawa 1983.

Kuczyński W., Po wielkim skoku, Warszawa 1981.

Kurowski S., Historyczny proces wzrostu gospodarczego. Analiza trendów sekularnych na podstawie produkcji żelaza i stali, Warszawa 1963.

Poland. Reform, Adjustment, and Growth, t. I: The Main Report, the Economic System, Washington 1987.

Reforma gospodarcza: propozycje, tendencje, kierunki dyskusji, red. R. Krawczyk, Warszawa 1981.

Tymiński M., Centralnie planowana ucieczka z peryferii. Wzrost gospodarczy Polski na tle Hiszpanii w latach 1950-1975, „Roczniki Dziejów Społecznych i Gospodarczych” 2012, t. LXXII, s. $155-188$. 
U źródet polskiego kryzysu, red. A. Müller, Warszawa 1985.

Witczak-Haugstad A., A Discipline Divided. Polish Economists and the Communist Regime, 1945-1960, Trondheim 2008.

Ząbkiewicz A., Koncepcja zagranicznej polityki kredytowej w Polsce w latach 1970-1980, Wrocław 1992.

Zieliński J.G., New Polish Reform Proposals, „Soviet Studies” 1980, t. XXXII, nr 1, s. 5-27.

Piotr Koryś - dr hab.; Katedra Historii Gospodarczej, Wydział Nauk Ekonomicznych Uniwersytetu Warszawskiego. Zajmuje się badaniem modernizacji ziem polskich w perspektywie historycznej. E-mail: pkorys@wne.uw.edu.pl.

Piotr Koryś - PhD with habilitation; Chair of Economic History, Faculty of Economic Sciences, University of Warsaw. Deals with the study of modernisation of the Polish lands in a historical perspective. E-mail: pkorys@wne.uw.edu.pl.

Maciej Tymiński - dr hab.; Katedra Historii Gospodarczej, Wydział Nauk Ekonomicznych Uniwersytetu Warszawskiego. Zainteresowania badawcze: historia gospodarcza czasów komunizmu w Polsce, przede wszystkim znaczenie aparatu partyjnego $\mathrm{w}$ gospodarce, problem rozwoju ziem polskich w XIX i XX w., wpływ zmian instytucjonalnych na zachowania społeczne w gospodarce. E-mail: mtyminski@wne.uw.edu.pl.

Maciej Tymiński - PhD with habilitation; Chair of Economic History, Faculty of Economic Sciences, University of Warsaw. Research interests: economic history of the communist era in Poland, in particular the significance of the party apparatus in the economy, the problem of development of the Polish lands in the 19th and 20th centuries, the impact of institutional changes on social behaviour in the economy. E-mail: mtyminski@wne.uw.edu.pl. 